\title{
ANALISIS PENGARUH SALES TRAINING TERHADAP EFEKTIVITAS PENJUALAN DENGAN DIMEDIASI KINERJA PENJUALAN (MEDICAL REPRESENTATIF)
}

\author{
Heppy Purbasari ${ }^{1}$, Andri Veno ${ }^{2}$ \\ ${ }^{1}$ Universitas Muhammadiyah Surakarta \\ hp123@ums.ac.id \\ ${ }^{2}$ Universitas Muhammadiyah Surakarta \\ veno.focus@gmail.com
}

\begin{abstract}
This research aims to examine an impact of fiscal decentralization, internal control system, and local government performance examination to the local government financial accountability. As Local autonomy implemented in Indonesia in 1999, it has impacted to several financial reform in Indonesia such as fiscal decentralization calculation, new model of internal control system, new criteria of local government performance and also local financial report accountability. This study collected secondary data from Badan Pemeriksa Keuangan Republik Indonesia by using 117 local government in Java Island as population. The study used purposive sampling method that consists of 106 local government that were analyzed by linear regression by using SPSS 21. The result showed that internal control system has significant impact to the local government financial accountability. However, fiscal decentralisation and local government performance examination has no significant influence to local government financial accountability.
\end{abstract}

Key word : Decentralisation Fiscal, Internal Control System, Local Government Performance, Local Government Financial Accountability.

\section{Abstrak}

Sales training merupakan segala kegiatan yang terkait dengan penjualan di dalam perusahaan. Sales training merupakan kunci sukses dalam menghasilkan proses pembelian. Penelitian ini berusaha memecahkan masalah tentang sales training, kinerja dan efektivitas penjualan pada Perusahaan Farmasi Multinasional, dengan menggambarkan suatu obyek penelitian yaitu dengan jalan menyimpulkyan, menyusun, menganalisis dan mengumpulkan data-data secara kuantitatif. Dari hasil analisis uji persamaan 2 menunjukkan bahwa sales training berpengaruh positif signifikan terhadap efektivitas penjualan, sehingga setiap peningkatan nilai sales training tinggi maka akan meningkatkan nilai kinerja penjualan, sedangkan untuk kinerja penjualan di Perusahaan Farmasi Multinasional berpengaruh positif signifikan terhadap efektivitas penjualan, sehingga setiap peningkatan nilai kinerja penujualan tinggi maka akan meningkatkan nilai efektivitas penjualan. Maka dapat diambil garis besar bahwa sales training berpengaruh positif signifikan terhadap efektivitas penjualan secara tidak langsung melalui kinerja medical representatif di Perusahaan Farmasi Multinasional. Jadi Kinerja Penjualan dapat memediasi pengaruh Sales training terhadap efektivitas penjualan, dari uji mediasi terbukti secara parsial (partially mediated).

Kata Kunci: Sales Training, Kinerja penjualan, Efektivitas Penjualan, partially mediated

\section{PENDAHULUAN}

Perusahaan

farmasi untuk

mengembangkan maupun meningkatkan

efektivitas penjualan produk atau jasanya. Kinerja tidak serta merta dapat dioptimalkan tanpa melalui faktor pendukung, karena setiap perubahan pasti membutuhkan upaya untuk merubahnya. Ada banyak faktor yang dapat berpengaruh terhadap kinerja karyawan, misalnya penggunaan media pendukung kerja, pelatihan, motivasi eksternal/internal, dan lain sebagainya.

Seiring dengan peningkatan kompetisi dan kemajuan teknologi, 
organisasi-organisasi terus mencari cara untuk menyesuaikan diri dengan perubahan lingkungan bisnis. Hal ini berlaku dalam konteks personal selling dimana tenaga penjual merupakan kunci sukses dalam menghasilkan proses pembelian. Personal selling merupakan sarana efektif untuk membangun preferensi, keyakinan, dan tindakan pembelian (Kotler, 2003: 580).

Persaingan yang ketat saat ini mengacu pada pasar global, dan teknologi yang terus berkembang, khususnya dalam bidang telekomunikasi (Wilson, 2000). Adanya perubahan tersebut membutuhkan peningkatan keahlian dari tenaga penjual yang dapat diperoleh melalui training (Filipczak et al, 1991). Jika suatu perusahaan ingin bertahan, maka perusahaan harus memberikan perhatian yang besar terhadap sales training mereka. Dikatakan oleh Roman et al. (2002) bahwa sales training mempengaruhi kinerja tenaga penjual dan orientasi pelanggan, sehingga kinerja tenaga penjual dan orientasi pelanggan dipengaruhi oleh adanya sales training.

Uraian diatas menunjukan adanya research gap yang mendasari dilakukannya penelitian ini. Oleh karena itu, peneiltian ini akan mencoba untuk mengetahui seberapa besar peran sales training terhadap kinerja medical representatif dalam meningkatkan efektivitas penjualan. Kinerja perusahaan sendiri akan memfokuskan pada kinerja karyawannya, salah satunya adalah kinerja dari medical representatif dalam menawarkan produk pada pelanggan maupun pihak yang membutuhkan. Kinerja sendiri adalah kesediaan seseorang atau kelompok orang untuk melakukan sesuatu kegiatan dan menyempurnakannya sesuai dengan tanggung jawab dengan hasil yang diharapkan (Rivai dan Basri, 2005).

Medical Representatif merupakan ujung tombak dalam industri farmasi, begitu juga dengan Perusahaan Farmasi Multinasional. Peran tenaga penjualan dalam meningkatkan pertumbuhan penjualan telah lama menjadi salah satu strategi pemasaran. Dengan peran tenaga penjualan maka perusahaan akan mampu menjalin hubungan yang dekat dan baik dengan pelanggan (Smith et al., 2000). Disamping itu, Perusahaan Farmasi Multinasional meningkatkan penjualan dan profitabilitas dan loyalitas pelanggan melalui tenaga penjual yang unggul. Produk-produk Perusahaan Farmasi Multinasional memiliki harga yang lebih premium dibandingkan produk farmasi lokal tentunya banyak memiliki pesaing di industri farmasi. Untuk dapat memasarkan produk-produk tersebut, maka Perusahaan Farmasi Multinasional sangat membutuhkan peran dari tenaga penjualan (Medical Representatif). Peran dari medical representatif di Perusahaan Farmasi Multinasional untuk memperkenalkan dan memasarkan produk-produk tersebut kepada customer (HCP/Dokter) yang pada akhirnya dapat mendatangkan penjualan bagi Perusahaan Farmasi Multinasional. Oleh karena itu peran dari medical 
representatif harus mendapat perhatian, sehingga kinerja dari medical representatif tersebut semakin meningkat dan efektivitas penjualan tercapai.

Selain dalam memasarkan produkproduk tersebut seorang medical representatif juga harus meningkatkan keahliannya yang dapat dicapai melalui sales training dan mengunakan fasilitas yang memadai. Dengan adanya sales training ini diharapkan akan meningkatkan kinerja para medical representatif di Perusahaan Farmasi Multinasional sehingga efektivitas penjualan juga dapat ditingkatkan. Berdasarkan latar belakang masalah di atas, maka ingin mengetahui mengenai kinerja para medical representatif dalam meningkatkan efektivitas penjualan mereka. Serta telah sejauh mana penggunaan adanya sales training terhadap kinerja medical representatif di Perusahaan Farmasi Multinasional.

\section{KAJIAN TEORI DAN PENGEMBANGAN HIPOTESA Kinerja Tenaga Penjualan}

Kinerja dari seorang karyawan adalah bagian dari kinerja organisasi karena kinerja organisasi memiliki ketergantungan dengan kinerja kelompok, dimana kelompok kerja yang dimaksud adalah kinerja tenaga penjual. Sedangkan menurut Johnston dan Marshall (2000) menyatakan bahwa kinerja merupakan evaluasi perilaku untuk mencapai tujuan organisasi. Dengan kata lain, kinerja merupakan elemen normatif yang mencerminkan perilaku tenaga penjual, dan sesuai atau tidak sesuai dengan tujuan perusahaan. Pengertian kinerja tenaga penjual menurut Challagala dan Shervani (1996) merupakan suatu tingkat dimana tenaga penjualan dapat mencapai target penjualan yang di tetapkan pada dirinya.

Secara umum guna meningkatkan kinerja tenaga penjual salah satu strategi yang dapat diaplikasikan adalah dengan pengembangan sumber daya manusia secara optimal yang memilki kompetensi dan komitmen yang tinggi terhadap peningkatan kinerja individu dan kinerja perusahaan (Hasibuan dalam Ridwan et al., 2012). Sehingga dari hal tersebut akan membawa perusahaan menuju tingkat yang lebih tinggi dari pada sebelumnya. Faktor penentu kinerja secara umum dapat dikelompokkan menjadi tiga, yaitu faktor individual, psikologi dan organisasi. Karena dari ketiga hal tersebut memiliki banyak pengaruh terhadap kinerja dari karyawan dalam hal ini tenaga penjual. Selain faktor penentu, Roman et al. (2002) menyatakan bahwa kinerja dalam efektivitas penjualan terdapat beberapa indikator atau pengukuran yaitu lingkungan dan faktor organisasi (kondisi ekonomi, kondisi pasar) yang dapat menjadi dasar dalam kinerja sales.

Untuk memberikan pengukuran terhadap kinerja tenaga penjualan, peneliti menggunakan indikator sebagai berikut: kemampuan mencapai target penjualan, kemampuan memperoleh pelanggan baru, kemampuan 
meningkatkan prosentase pertumbuhan. Baldauf et al. (2001), Barker (1999).

Sales Training

Aguinis dan Kraiger (2009) menyatakan bahwa training adalah sebuah pendekatan sistematis untuk pembelajaran mengenai pengetahuan, keterampilan, dan sikap individu dalam rangka meningkatkan efektivitas individu, tim, dan organisasi. Pengertian tersebut sebelumnya telah diungkapkan oleh Goldstein dan Ford dalam Aguinis dan Kraiger, (2009) dimana training organisasi mengacu pada pendekatan sistematis untuk pembelajaran dan pengembangan guna meningkatkan efektivitas individu, tim dan organisasi.

Definisi training menurut Gomes (2001) menyatakan bahwa pelatihan yang diberikan kepada karyawan yang berfungsi untuk memperbaiki kinerja karyawan atas suatu pekerjaan yang menjadi tanggung jawabnya. Sehingga dari berbagai pengertian di atas dapat disimpulkan bahwa training adalah suatu usaha maupun pendekatan sistematis untuk meningkatkan kualitas kerja dari individu untuk tim dan selanjutnya dapat memberikan dampak positif bagi organisasi/perusahaan yang menaungi.

Barber (2004) di dalam training memperbolehkan atau membiarkan untuk mendapatkan inovasi yang lebih besar dan keahlian diam-diam. Hal ini memiliki arti bahwa sikap atau tingkah laku yang merupakan bentuk pembelajaran informal dan dapat juga berguna dalam kinerja yang efektif. Keuntungan dengan adanya training bagi karyawan dapat dijadikan acuan dari sebuah perusahaan, sejauh mana perusahaan dalam memberikan ilmu lebih pada karyawannya. Sedangkan menuurut Aguinis dan Kurt (2009) training mungkin secara bertahap diperbolehkan atau diizinkan pada kinerja karyawan.Namun ketika trainer memberikan tekanan pada peserta, maka training seperti ini dapat memberikan tekanan berupa suara gaduh/bising, adanya batasan waktu, sehingga tekanan ini mampu mempengaruhi kinerja karyawan. Artinya pelatihan yang berlebih atau tidak dapat diterima oleh karyawan/peserta training dapat menimbulkan sebuah kelemahan, dimana karyawan akan merasa tertekan, takut, dan tidak nyaman dalam mengikuti pelatihan.

Tujuan training menurut Roman et al. (2002) yaitu untuk meningkatkan kinerja yang didasarkan atas tingkah laku dan tujuan yang ingin dicapai. Menurut Roman et al. (2002) yang menyatakan bahwa training dapat dipengaruhi oleh beberapa hal yang mampu mempengaruhi penjualan yaitu adanya faktor lingkungan (kondisi pasar dan persaingan/kompetisi) yang tidak terkendali oleh perusahaan atau sales itu sendiri.

Pengukuran ini dilakukan dengan cara mengukur penanaman skill pada training, metode yang digunakan dan isi atau konten dari training. Pertama, penanaman skill dapat diukur dari perusahaan yang telah memberikan skill kepada sales ketika training, dan 
perusahaan yang tidak memberikan subsidi atau bantuan ketika sales training.Kedua, metode dapat diukur dari banyaknya perusahaan yang menyediakan training pada bidangnya, kursus yang dikelola oleh trainer, kursus yang dikelola oleh penyedia eksternal, kursus jangka pendek eksternal (lima hari atau kurang dari itu), program training eksternal (enam hari atau lebih), training dari perusahaan secara langsung, dan pembelajaran secara terbuka atau berkala. Ketiga, konten atau isi yang dapat diukur dari kebijakan perusahaan, teknik penjualan, kondisi pasar dan pengetahuan konsumen, pendidikan sales, penguasaan komputer dan kerjasama.

Dalam penelitian ini, peneliti menggunakan indikator sales training sebagai berikut : manfaat sales training, intensitas training, aplikasi training dalam pekerjaan, materi dan sarana prasarana, kompetensi trainer. (Tiatira, 2006).

\section{Efektivitas Penjualan}

Perusahaan memiliki orientasi pada pemasaran hasil produknya, sehingga apa yang dikerjakan pada proses pengolahan akan sangat diperhatikan sampai dengan pemasaran produk tersebut. Efektivitas penjualan menjadi kewajiban bagi setiap perusahaan guna memberikan income yang optimal.Menurut Michel dan Bascoul (2008) efektivitas penjualan adalah banyaknya kegiatan per penjualan representatif dalam waktu tertentu. Sedangkan menurut Roman et al. (2002) efektivitas penjualan dapat dilihat dari sales yang membutuhkan ide bagaimana proses berjualan agar lebih produktif, sehingga sales harus meningkatkan kinerjanya.

Sehingga dari beberapa teori tersebut menunjukkan bahwa efektivitas penjualan adalah banyaknya kegiatan per penjualan representatif dalam waktu tertentu untuk mencapai tujuan dengan cara meningkatkan kinerja sales melalui ide-ide agar proses berjualan yang diharapkan lebih produktif. Menurut Humpreys dan Williams dalam Theresia (2006) penambahan nilai yang terdapat pada tenaga penjualan melibatkan penggunaan pengalaman dan pengetahuan dalam merespon permintaan pembeli, seperti adanya kejelasan dalam memberikan informasi tentang produk yang ditawarkan, ketepatan proses pemesanan, pemecahan masalah, dan pengaduan serta mampu memberikan solusi yang tepat kepada pembeli. Seara umum tugas seorang penjual maupun sales adalah memberikan pelayanan yang lebih bagi pembeli, karena hal tersebut dapat meningkatkan efektivitas penjualan dimasa yang akan datang.

Pengukuran terhadap efektivitas penjualan, indikator penelitian dari Roman et al. (2002) yang menyatakan bahwa efektivitas penjualan diukur dari perubahan banyak sedikitnya penjualan, penyediaan pasar, dan kemampuan mengelola keuntungan dalam waktu dua tahun terakhir. Berbeda dengan Michel dan Bascoul, (2008) yang menyatakan bahwa dalam penelitian kuantitatif, 
keefektifan penjualan dapat diukur dari kegiatannya (banyaknya panggilan kepada sales), sedangkan penelitian kualitatif dapat diukur dari rasio produktivitas penjualan (jumlah panggilan kepada sales dari total panggilan).

Untuk memberikan pengukuran terhadap efektivitas penjualan dalam penelitian ini, maka peneliti mengambil indikator volume dan growth terhadap penjualan yang telah dilakukan oleh para tenaga penjual/sales. Karena dari indikator tersebut tingkat akurasinya lebih tepat dan nyata dalam hal

\section{METODE PENELITIAN}

\section{Lokasi Penelitian}

Lokasi penelitian ini adalah di Surakarta dan Daerah Istimewa Yogyakarta (DIY). Populasi dalam penelitian ini adalah seluruh tenaga penjualan Perusahaan Farmasi Multinasional area Surakarta dan Daerah Istimewa Yogyakarta yang berjumlah 128 tenaga penjual (sales).

\section{Jenis Penelitian dan Metode Analisis}

Jenis data yang digunakan dalam penelitian ini adalah data persepsi yang merupakan jenis data yang berupa sikap, pengalaman dan opini dari responden. Penelitian yang dilakukan merupakan jenis penelitian kuantitatif, dengan alasan bahwa penelitian ini berusaha memecahkan masalah tentang sales training, kinerja dan efektivitas penjualan pada Perusahaan Farmasi Multinasional, dengan menggambarkan suatu obyek penelitian yaitu dengan jalan perolehan pemasukan perusahaan. Berdasarkan temuan penelitian terdahulu yang terdapat ketidak konsistenan dalam temuan, dari hal tersebut maka peneliti merumuskan sebagai berikut :

H1: Ada pengaruh dari sales training terhadap kinerja medical representatif di Perusahaan Farmasi Multinasional.

H2 : Ada pengaruh dari sales training terhadap efektivitas penjualan secara tidak langsung melalui kinerja medical representatif di Perusahaan Farmasi Multinasional.

menyimpulkan, menyusun, menganalisis dan mengumpulkan data-data secara kuantitatif.

Penelitian ini menggunakan daftar pertanyaan atau kuesioner dalam proses pengumpulan data. Menurut Sugiyono (2012: 192) Kuesioner merupakan teknik pengumpulan data yang dilakukan dengan cara memberi seperangkat pertanyaan atau pernyataan tertulis kepada responden untuk dijawabnya.Kuesioner atau daftar pertanyaan telah disiapkan peneliti untuk dijawab oleh responden melalui pertanyaan-pertanyaan tertutup (alternatif jawaban telah disiapkan oleh peneliti) dan pertanyaan terbuka untuk mendapatkan data tentang dimensidimensi dari konstruk-konstruk yang sedang dikembangkan dalam penelitian ini. 


\section{Teknik Analisis data Model Regresi}

Analisis regresi mengukur

kekuatan hubungan antara dua variabel atau lebih, juga menunjukkan arah hubungan antara variabel dependen dengan variable independen (Ghozali, 2006). Model regresi yang digunakan dalam penelitian ini adalah :

Persamaan $1: \mathrm{KP}=\alpha+\beta_{1} \mathrm{ST}+\varepsilon$

Persamaan 2: EP $=\alpha+\beta_{1} \mathrm{ST}+\beta_{2} \mathrm{KP}+$ $\varepsilon$

Keterangan:

KP : Kinerja Penjualan

EP : Efektivitas Penjualan

$\alpha / \mathrm{a} \quad$ : Konstanta

$\mathrm{b}_{1} / \beta_{1}$ : Koefisien regresi variabel Sales Training

$\mathrm{b}_{2} / \beta_{2}$ : Koefisien regresi variabel Kinerja Penjualan

ST : Variabel Sales Training

$\varepsilon \quad$ : Measurement error

\section{UJi F (Uji Ketepatan Model)}

Uji $F$ yaitu untuk menguji apakah semua variabel independen atau bebas yang dimasukkan dalam model memiliki pengaruh secara bersama-sama terhadap variabel dependen/terikat. Uji statistik F pada dasarnya digunakan untuk mengetahui apakah(seberapa besar) model regresi yang dapat digunakan untuk memprediksi variabel dependen Priyatno (2013).

\section{Koefisien Diterminasi $\left(\mathbf{R}^{2}\right)$}

Koefisien ini digunakan untuk mengetahui seberapa jauh kekuatan variabel independen mampu menjelaskan terhadap perubahan variabel dependen, dengan menggunakan rumus:

$$
\begin{aligned}
& \mathrm{R}^{2}=\frac{\sum(\hat{\mathrm{Y}}-\tilde{\mathrm{Y}})}{\sum(\mathrm{Y}-\tilde{\mathrm{Y}})} \text { Gujarati (2006) } \\
& \hat{\mathrm{Y}} \quad: \text { Y estimasi } \\
& \hat{\mathrm{Y}} \quad: \text { Y rata-rata }
\end{aligned}
$$

Nilai koefisien $\mathrm{R}^{2}$ berkisar 0 sampai 1 , jika nilai koefisien $R^{2}$ hitung semakin mendekati angka 1 maka variabel independennya semakin kuat berpengaruh terhadap variabel independennya.

\section{Uji t (Uji Hipotesis)}

Menurut Imam Ghozali (2006) uji statistik t pada dasarnya menunjukkan seberapa jauh pengaruh satu variabel independen secara individual dalam menerangkan variabel dependen; pengujian dilakukan dengan menggunakan signifikan level 0,05 $(\alpha=5 \%)$. Penerimaan atau penolakan hipotesis dilakukan dengan kriteria :

1) Jika nilai signifikan > 0,05 maka hipotesis ditolak (koefisien regresi tidak signifikan); Ini berarti secara parsial variabel independen tidak mempunyai pengaruh secara signifikan terhadap variabel dependen.

2) Jika nilai signifikan $\leq 0,05$ maka hipotesis diterima (koefisien regresi signifikan); Ini berarti secara parsial variabel independen tersebut mempunyai pengaruh yang signifikan terhadap variabel dependen.

Ada tiga kemungkinan hasil dari uji mediasi, yaitu (1) mediasi terbukti secara penuh (fully mediated), (2) mediasi terbukti secara parsial (partially 
mediated) dan (3) mediasi tidak terbukti. Menurut Baron dan Kenny (1986), mediasi penuh terjadi jika memenuhi kriteria:

a. Koefisien jalur dari variabel bebas ke variabel intervening signifikan.

b. Koefisien jalur dari variabel intervening ke variabel terikat signifikan.

c. Koefisien jalur dari variabel bebas ke variabel terikat, yang dikontrol oleh variabel intervening tidak signifikan.

Berdasarkan kriteria dalam test mediasi, maka secara otomatis pengujian

Tabel 1.1

Objek bedasarkan Tahun, Jenis Kelamin dan rata-rata bekerja

\begin{tabular}{|l|c|c|c|c|c|}
\hline \multirow{2}{*}{ No } & Sampel & $\begin{array}{c}\text { Rata-rata } \\
\text { usia } \\
\text { (tahun) }\end{array}$ & \multicolumn{2}{|c|}{$\begin{array}{c}\text { Rata-rata Jenis } \\
\text { kelamin }\end{array}$} & \multirow{2}{*}{$\begin{array}{c}\text { Rata-rata lama } \\
\text { bekerja (tahun) }\end{array}$} \\
\cline { 4 - 5 } & & $\mathbf{L}$ & $\mathbf{P}$ & \\
\hline 1 & 128 & 32,93 & 52 & 76 & 7,2 th \\
\hline
\end{tabular}

Sumber diolah tahun 2017

Berdasarkan data yang diperoleh mengenai 128 tenaga penjual yang diperoleh yaitu memiliki rata-rata usia penjual adalah 32,93 dibulatkan menjadi 33 tahun, jadi rata-rata tenaga penjual di area Surakarta dan Yogyakarta memiliki usia rata-rata 33 tahun. Sedangkan jenis kelamin tenaga penjual di area Surakarta dan Yogyakarta diantaranya terdapat 52 adalah laki-laki dan 76 adalah perempuan, jadi dari rata-rata tenaga penjual di area Surakarta dan Yogyakarta di dominasi jenis kelamin Perempuan untuk tenaga penjualnya. Untuk selanjutnya dari rata-rata lama bekerja tenaga penjual di area Surakarta dan Yogyakarta rata-rata lama bekerjanya yaitu 7 tahun lebih sudah dalam pengaruh langsung dan tidak langsung harus dilakukan.

\section{Hasil dan Pembahasan \\ Deskriptif Statistik}

Objek penelitian yang digunakan dalam penelitian ini yaitu seluruh tenaga penjual (medical representatif) Perusahaan Farmasi Multinasional diarea Surakarta dan Yogyakarta. Dimana terdapat 128 tenaga penjual sebagai sampel dalam penelitian ini. Berikut deskripsi dari sampel 128 tenaga penjual 
Berdasarkan persamaan Regresi diatas (persamaan 1) dapat maka dijelaskan Koefesien regresi Sales Training sebesar 0,43 berarti bahwa setiap peningkatan nilai Sales training, mengakibatkan kinerja penjualan meningkat.

Persamaan 2 :

Efektivitas Penjualan $=1,89+0,32$ Sales Training $+\mathbf{0 , 5 7}$ Kinerja Penjualan $+\varepsilon$

Berdasarkan persamaan Regresi diatas (persamaan 2) dapat maka dijelaskan Koefisien regresi Sales Training sebesar 0,32 berarti bahwa setiap penambahan nilai Sales training, maka efektivitas penjualan meningkat. sedangkan Koefesien regresi Kinerja Penjualan sebesar 0,57 berarti bahwa setiap penambahan nilai Kinerja Penjualan, maka efektivitas penjualan bertambah.

\section{Uji Ketepatan Model (Uji F dan $\mathbf{R}^{\mathbf{2}}$ )}

Untuk mengetahui apakah model yang digunakan dalam penelitian ini tepat ataukah tidak dapat diidentifikasi dari hasil uji F dan Uji $\mathrm{R}^{2}$

\section{Uji F}

Dari hasil uji Anova atau $\mathrm{F}$ test (goodness of fit), di peroleh nilai $\mathrm{F}_{\text {hitung }}$ adalah sebesar 42,00 dengan nilai probabilitas $0,000<0,05$, Untuk persamaan Regresi 1 maka hipotesis $\mathrm{H}_{0}$ dalam penelitian ini ditolak $\mathrm{H}_{\mathrm{A}}$ diterima. Berarti model yang digunakan dinyatakan Fit atau baik dengan arti bahwa model layak digunakan.
Sedangkan untuk hasil uji Anova atau F test, di peroleh nilai $F_{\text {hitung }}$ adalah sebesar 47,91 dengan nilai probabilitas $0,000<$ 0,05 . Demikian juga untuk persamaan Regresi 2, hipotesis $\mathrm{H}_{0}$ dalam penelitian ini ditolak $\mathrm{H}_{\mathrm{A}}$ diterima. sehingga model yang digunakan dinyatakan baik dan dapat digunakan.

\section{Koefisien Determinasi $\left(\mathbf{R}^{2}\right)$}

Uji ketepatan model juga dapat diidentifikasi dengn pengujian koefisien determinasi $\left(\mathrm{R}^{2}\right)$. Berdasarkan hasil pengujian regresi persamaan 1 diperoleh nilai $\mathrm{R}^{2}$ ( $R$-square) sebesar 0,250 yang berarti Sales Training dapat menjelaskan Kinerja Penjualan sebesar $25 \%$, sedangkan sisanya sebesar $75 \%$ dijelaskan oleh variabel lain yang tidak dijelaskan dalam model ini. Sedangkan hasil pengujian regresi persamaan 2 diperoleh nilai $\mathrm{R}^{2}$ (R-square) sebesar 0,431 yang berarti Sales Training dan Kinerja Penjualan dapat menjelaskan Efektivitas Penjualan sebesar 43,1 \%, sedangkan sisanya sebesar $65.9 \%$ dijelaskan oleh variabel lain yang tidak dijelaskan dalam model ini.

\section{Uji Ketepatan Parameter Penduga (Uji t)}

Berdasarkan hasil Uji statistik dengan bantuan eviews 7 maka dapat dijelaskan sebagaimana berikut ini:

\section{Persamaan 1 :}

Uji ketepatan parameter digunakan Uji t persamaan 1, untuk mengetahui pengaruh sales training secara parsial terhadap kinerja penjualan. Berdasarkan 
hasil uji statistik dengan bantuan eviews 7 maka dapat dijelaskan sebagaimana berikut ini: Uji ketepatan parameter digunakan Uji t persamaan 1 yaitu sales training mempunyai nilai koefisien regresi 0,437 dengan $t_{\text {hitung }}$ sebesar 6,481 dan $p$-value sebesar $0,00<0,05$, maka dapat disimpulkan bahwa sales training berpengaruh positif signifikan menambah kinerja penjualan.

Persamaan 2 :

Sedangakan Uji ketepatan parameter digunakan Uji t persamaan 2, Sales training mempunyai nilai koefisien

\section{KESIMPULAN DAN SARAN}

Hasil analisis data menjelaskan pengaruh antara variabel-variabel yang sedang dikembangkan dalam penelitian ini. Pengujian hipotesis menggunakan uji t-statistik dengan signifikansi dibawah 0,05 atau $5 \%$.

Berikut adalah penjelasan untuk setiap hubungan antar variabel yang dihipotesiskan :

1) Pengaruh dari sales training berpengaruh positif signifikan terhadap kinerja medical representatif di Perusahaan Farmasi Multinasional. Hasil analisis uji persamaan 1 menunjukkan bahwa sales training berpengaruh positif signifikan terhadap kinerja medical representatif di Perusahaan Farmasi Multinasional, maka itu berarti setiap peningkatan nilai sales training tinggi maka akan meningkatkan nilai kinerja penjualan di Perusahaan Farmasi Multinasional. regresi 0,321 dengan $t_{\text {hitung }}$ sebesar 3,781 dan $p$-value sebesar $0,00<0,05$, maka dapat disimpulkan bahwa sales training berpengaruh positif signifikan menambah efektivitas penjualan. Sedangkan untuk kinerja penjualan mempunyai nilai koefisien regresi 0,575 dengan $t_{\text {hitung }}$ sebesar 5,928 dan p-value sebesar $0,00<0,05$, maka dapat disimpulkan bahwa kinerja penjualan berpengaruh positif signifikan menambah efektivitas penjualan.

2) Pengaruh dari sales training berpengaruh positif signifikan terhadap efektivitas penjualan secara tidak langsung melalui kinerja medical representatif di Perusahaan Farmasi Multinasional.

Kesimpulan dari penelitian ini yaitu Hasil analisis uji persamaan 2 menunjukkan bahwa sales training berpengaruh positif signifikan terhadap efektivitas penjualan, sehingga setiap peningkatan nilai sales training tinggi maka akan meningkatkan nilai efektivitas penjualan, sedangkan untuk kinerja penjualan di Perusahaan Farmasi Multinasional berpengaruh positif signifikan terhadap efektivitas penjualan, sehingga setiap peningkatan nilai kinerja penujualan tinggi maka akan meningkatkan nilai efektivitas penjualan. Maka dapat diambil garis besar untuk persamaan 2 yaitu sales training berpengaruh positif signifikan terhadap efektivitas penjualan secara tidak langsung melalui kinerja medical 
representatif di Perusahaan Farmasi Multinasional. Jadi Kinerja Penjualan dapat memediasi pengaruh Sales training terhadap efektivitas penjualan, dari uji mediasi terbukti secara parsial (partially mediated).

Saran dalam penelitian ini yaitu sebagai berikut; Bagi perusahaan Farmasi Multinasional di area Surakarta dan Yogyakarta, hasil ini dapat digunakan sebagai strategi perusahaan untuk dapat meningkatkan persaingan pasar maka kinerja penjualan perlu adanya peningkatan dan akhirnya berdampak pada meningkatnya efektivitas dalam penjualan. Mengingat persaingan produk yang berkualitas maka bagi perusahaan farmasi multinasional di area Surakarta dan Yogyakarta efektivitas penjualan sangatlah penting dalam memenangkan persaingan pasar. Bagi akademisi harapannya penelitian ini bisa memberikan sumbangsih pengetahuan dan wawasan secara teoritis bidang ilmu yang terkait dengan pemasaran. Sedangkan untuk peneliti ini diharapkan bisa menjadi acuan dan bahan pembanding serta wawasan untuk penelitian selanjutnya dan perkembangan ilmu yang bersangkutan.

\section{DAFTAR PUSTAKA}

Journal in Print Format

One Author

Barber, J. 2004. Skill Upgrading within Informal Training: Lessons from the Indian Auto Mechanic. Int.F.Train.Dev. 8:128-39
Theresia, Dorkas, T. 2006. Analisis Pengaruh Sistem Kontrol dan Sales Training terhadap Kinerja Tenaga Penjualan untuk Meningkatkan Efektivitas Penjualan (Studi Kasus Pada Bank ABN AMRO di Semarang). Tesis. Semarang: Universitas Diponegoro.

Wilson, Philip H., Strutton, David and Farris II, M. Theodore, 2002, "Investigating the Perceptual Aspect of Sales Training", Journal of Personal Selling \& sales Management, Vol. XXII, No. 2, pp. 77-86

Wilson, D.T. 2000. Deep Relationships: The Case of The Vanishing Salesperson. Journal of Personal Selling and Sales Management. Vol 2, No 1, pp: 53-61

Two to Seven Authors [List all authors]

Aguinis, Herman dan Kraiger, Kurt. 2009. "Benefits of Training and Development for Individuals and Teams, Organizations and Society". The Annual Review of Psychology. 2009. No. 60, pp: 451474.

Baldauf, A., David, C.W. \& Piercy, N.F. 2001. "Examining Business Strategy, Sales Management, and Salesperson Antecedents of Sales Organization Effectiveness". Journal of Personal Selling \& Sales Management, Vol.21,No.2: 109122 (Spring).

Baron, R.M and Kenny, D.A. 1986. "The Moderator-Mediator

Variable 
distinction in Social Psychological Research: Jornal of Personality and Social Psycholog". 51, 11731182 .

Challagalla, Goutam, N., dan Shervani, A., Tassaduq. 1996. "Dimension and Types of Supervisory Control: Effect on Salesperson Performance and Satisfication". Journal of Marketing. Vol. 60, No.1, pp: 89105.

Elly, Aprillia, K., dan Mursid, Ali. 2015. "Pengaruh Pengawasan, Kepuasan pada Pimpinan, dan Komitmen Tenaga Penjual pada Kinerja Tenaga Penjual". Jurnal EBBANK. Vol. 6, No. 1, pp: 19-32.

Michel, Jean, Moutotdan Bascoul, Ganael. 2008. "Effects of Sales Automation use on Sales Force Activities and Customer Relationship Management Processes". Journal of Personal Selling \& Sales Management. Vol. 28, No. 2, pp: 167-184.

\section{Books, Chapters In Books, Reports,} Etc.

One Author

Filipczak, R, Geber, B and Thompson, B.L. 1991. Training Today: Sig Signs of The Future; Get in Line Soldier; Focus Shifts to Core Skill. Training. Vol 28, Januari, pp 1216.

Ghozali, Imam. 2005. Analisis Multivariate dengan program SPSS. Semarang : BadanPenerbit Universitas Diponegoro
Ridwan, Muhammad; Fudholi, Achmad; danPrasetyo, Edy, Nugroho. 2012. Pengaruh Desain Organisasi, Gaya Kepemimpinan dan Iklim Kerja terhadap Kinerja Karyawan. Jurnal Manajemen dan Pelayanan Farmasi. Vol. 2, No. 3, pp: 171177.

Rivai, Veithzal dan Basri. 2005. Performance Appraisal: Sistem yang Tepat untuk Menilai Kinerja Pegawai dan Meningkatkan Daya Saing Perusahaan. Jakarta: PT. Raja Grafindo Persad.

Roman, Sergio; Ruiz, Salvador dan Luis, Jose, Munuera. 2002. "The Effect of Sales Training on Sales Force Activity". European Journal of Marketing. Vol. 36, No. 11/12, pp: 1344-1366.

Smith, Kirk; Eli, Jones dan Edward, Blair. 2000. "Managing Sales Person Motivation in aTerritory Realignment". Journal of Personal Selling \& Sales Management. Vol. 20, No 4, pp: 215-226.

Gomes, Cardoso F. 2001. "Manajemen Sumber Daya Manusia". Andy Offset . Yogyakarta.

Gujarati, Damodar N. 2006. DasarDasar Ekonometrika. Jakarta: Erlangga

Kotler, Philip. 2003. Manajemen Pemasaran-Edisi Kesebelas. Jakarta: Indeks Kelompok Gramedia.

Sugiyono. 2012. Metode Penelitian Kombinasi (Mixed Methods). Bandung: CV Alfabeta. 
Johnston, MW and Greg W Marshall. 2000. "Sales Force Management". McGraw-Hill.

\section{Tesis}

Tiatira, Dorkas T. 2006. "Analisis Pengaruh Sistem Kontrol dan Sales Training terhadap Kinerja
Tenaga Penjualan untuk Meningkatkan Efektifitas Penjualan".

https://core.ac.uk/download/pdf/11 716877.pdf 
INVENTORY: Jurnal Akuntansi Vol. 3 No. 1 April 2019 